\title{
Changes in the Labour Market and Education in the Czech Republic in the Context of the Global Pandemic
}

\author{
Dana Linkeschová ${ }^{1, *}$, Alena Tichá $^{1}$ \\ ${ }^{1}$ BUT, Faculty of Civil Engineering, Institute of Structural Economics and Management, Veveři \\ 331/95, Brno, 60200 Czech Republic
}

\begin{abstract}
Research background: At a time when we are looking for ways to recover the economy most effectively from a global pandemic, digitalization represents a significant opportunity. This is a specific aspect of digitalization, i.e. automation through artificial intelligence-driven technologies, in various areas of society, particularly in the industry and related education.

Purpose of the article: The aim of this article is to present the changes in the labour market and education in the context of the global pandemic. Even after the end of the pandemic, it will be necessary to continue increasing productivity through the use of modem technologies. Education will no longer be tailored to one profession, as it has been so far, but shall emphasise interdisciplinarity, comprehensiveness, creativity and flexibility. The Fifth Industrial Revolution (Industry 5.0) will logically follow. It is a vision of the return of a man and his creativity to the production processes.

Methods: The paper analyses the survey of the international research into the global crisis caused by the pandemic using desk research and mathematical statistics methods.

Findings and added value: Many professions tend to be at risk as work becomes increasingly digitalized and automated. This article looks at the possible evolution of the market and the emergence of new professions that cannot be imagined now. Therefore, it is very important to focus education in all areas of society to prepare the graduates to be able to flexibly respond to changes in the labour market requirements.
\end{abstract}

Keywords: Global pandemics; labour market; education; managerial competencies; mathematical and quantitative methods

Classification JEL: A13; C1; J24; J44; I21; I15

\footnotetext{
* Corresponding author: linkeschova.d@ffce.vutbr.cz
} 


\section{Introduction}

COVID-19 is not the world's first pandemic, nor its worst, and probably not its last, as Philip A. Mackowiak notes in his article. (Mackowiak, 2021).

At a time when the ways to recover the economy most effectively from a global pandemic are looked for, digitalization represents a significant opportunity. Paradoxically, the crisis has accelerated digitalization, automation, robotics and the development of artificial intelligence in areas where it has been difficult to find their position so far. In the context of the global pandemic, increasing discussion of a revolution in industry and related education emerges. It concerns the process of digitalization and its specific aspect, i.e. automation through artificial intelligence (AI)-driven technologies, in various areas of society. "When comparing major influenza and coronavirus pandemics in recent history, it becomes clear that their similarities are not a mere coincidence" (Mujica et al).

The digital age is becoming part of everyday life and in many ways, we may not have noticed it. In 2015, the digital economy accounted for 4.2\% of global GDP and provided jobs for 17 million people worldwide, in addition to indirectly supporting another 15 million jobs. Between 2017 and 2019, the digital economy has already contributed by $8.3 \%$ to global GDP. The period of the Fourth Industrial Revolution is changing the way work and employment are viewed today. Even after the pandemic is over, it will be necessary to continue increasing productivity using modern technologies. Only doing so can counter the demographic trends that threaten the labour supply. Education will no longer be tailored to one profession, as it has been so far, but will emphasise interdisciplinarity, comprehensiveness, creativity and flexibility.

The human and economic costs of this pandemic continue to rise. Practices that once seemed peripheral have suddenly become central to the management of education and research (Gill, 2021).

\section{Theoretical background}

Gradual displacement of human labour and its replacement by robots can clearly be noticed in some professions. According to McKinsey's estimates (Randl, 2021), more than half of today's work activities in the Czech Republic could be automated using existing technologies, which corresponds to approximately 2.4 million jobs. The average scenario of technology introduction in the Czech Republic says that by 2030, 1.1 million jobs could be automated. Such a development would support the growth of sectors such as housing, manufacturing, transport, agriculture or construction, which have recently been facing labour shortages and at the same time have considerable scope for automation.

This means demands for new skills in many professions, as some specializations may disappear completely in the future. It will be crucial to provide rapid retraining of workers to mitigate the risk of a sharp rise in unemployment. Moreover, in parallel, start a completely newly focused education to prepare graduates for a versatile labour market. The results of the studies suggest a significant impact on the quality of life due to working conditions during the COVID-19 pandemic, with a significant impact especially on women and the youngest age groups. (Lizana et al., 2021) Young people and low-skilled workers are more vulnerable to unemployment than medium-skilled and high-skilled workers. This is because young and low-skilled workers experience a lack of high-level skills. (Nguyen et al., 2020)

It can be stated from previous surveys that change in the labour market due to the process of automation, robotics and digitalization will take place sooner or later, quickly or in a longer period, however, will not take place evenly and will affect some sectors and professions to more extent than the others. Certain groups of workers and certain segments of the economy will thus experience greater pressure related to the introduction of digitalization, automation 
and robotics than the others. This can lead to deepening social inequalities and increasing tensions in society. At the same time, however, this process is also an unprecedented opportunity to set appropriate functionalities in the society and to change the perception of both work and other attributes of the perception of a person as an individual and a member of the society. The variety of estimates that form part of individual reports can be seen in Table 1 below.

\section{Methodology}

Research methodology is based on the analysis of surveys of international research into the global crisis caused by the pandemic using the desk-research method (Travis 2016) and the methods of mathematical statistics.

The European Statistical System (ESS) guarantees the reliability of European statistics. (Czech Statistical Office, 2021)

It includes the EU Statistical Office (Eurostat) and statistical offices and other institutions of the EU member states. The aim of the European Social Survey (ESS) is to provide statistics that are harmonized, reliable, relevant and usable. The methods of statistical surveys are based on scientific statistical methods (Czech Statistical Office, 2021). Labour market and labour force surveys also apply these methods.

The Labour Force Sample Survey (LFSS) in the Czech Republic is carried out continuously by the Czech Statistical Office (CSO) in a randomly selected sample of households and is focused on determining the economic position of the population throughout the country. The LFSS enables a qualified estimate of the amount of employment in organizations and companies, including the independent activities of persons doing business in accordance with the Trade Licensing Act and other legal standards. The current structure of employment by gender, age and qualification, industry and character of employment of respondents is found out. Data on the number of working hours, concurrence of employment and labour mobility are also surveyed. The survey provides information on the total unemployment rate and its character, on the structure of the unemployed in terms of social, professional, qualification, unemployment duration aspect, etc., even in the territorial crosssection. This information is otherwise undetectable.

Since 2002, the LFSS questionnaire in the Czech Republic has been fully harmonized with the Eurostat standard and thus complies with the COUNCIL DECISION (EC) 577/98. However, the content and the structure of the Eurostat standard is subject to evolvement and in this context, the CSO makes regular partial adjustments to the questionnaire. The results of the survey serve as one of the aspects for the decision-making process on the allocation of EU funds to individual regions (CSO Czech Statistical Office, 2021).

\section{Results}

\subsection{Results of digitalization in the field of industry}

Based on international research, significant impacts on jobs due to digitalization, robotics and industrial automation can be expected. An overview of selected information from the reports of companies that deal with this issue is provided below. 
Table 1. An overview of the reported impacts on jobs

\begin{tabular}{|c|c|}
\hline Report & Statement \\
\hline Deloitte, Work automation & $\begin{array}{l}51 \% \text { of jobs will be exposed to high risk of automation, } \\
21 \% \text { to medium risk and } 28 \% \text { to low risk of automation } \\
\text { in the economy as a whole. }\end{array}$ \\
\hline Manpower Group, 2019 Report & $\begin{array}{l}24 \% \text { out of } 41 \% \text { that introduce automation in some } \\
\text { activities in the next } 2 \text { years, will create new jobs. }\end{array}$ \\
\hline $\begin{array}{l}\text { Summary report of the Central } \\
\text { Committee }\end{array}$ & $\begin{array}{l}\text { Within } 5 \text { years }-50 \% \text { of the skills required to perform } \\
\text { the profession will be replaced in } 11 \% \text { of jobs. } \\
\text { Within } 15 \text { years - technology will replace } 50 \% \text { of skills } \\
\text { in almost } 70 \% \text { of jobs. } \\
\text { Within } 30 \text { years - technology will replace more than } \\
50 \% \text { of skills in almost all professions. } \\
\text { The ratio of lost and newly created jobs will be } 5: 2 \text {. }\end{array}$ \\
\hline Industry 4.0 Initiative & There should be up to 2.5 new jobs per job lost. \\
\hline OECD Report & $\begin{array}{l}\text { Over the next } 20 \text { years, } 10 \% \text { of jobs will be at high risk } \\
\text { from automation and another } 35 \% \text { of jobs will undergo } \\
\text { significant changes. In absolute numbers, this means } \\
\text { that about } 408,000 \text { jobs will be at risk and there will be } \\
\text { a substantial change in approximately } 1.4 \text { million jobs. } \\
\text { This is one of the more optimistic forecasts, which may } \\
\text { nevertheless place a greater burden on social systems, } \\
\text { which will have to provide a higher percentage of the } \\
\text { unemployed population until the educational structure } \\
\text { of the population adapts to new demands and new } \\
\text { sectors stabilize. }\end{array}$ \\
\hline $\begin{array}{l}2019 \text { OECD Employment } \\
\text { Outlook }\end{array}$ & $\begin{array}{l}\text { Medium-skilled jobs are increasingly subject to } \\
\text { significant transformation. It is estimated that up to } \\
14 \% \text { of existing jobs could disappear due to } \\
\text { automation in the next } 15-20 \text { years. Another } 32 \% \text { of } \\
\text { jobs could change radically, due to the automation of } \\
\text { individual activities. }\end{array}$ \\
\hline
\end{tabular}

Source: Kotíková et al. (2019)

A question arises whether to worry about robotizing work due to possible job losses. The following figure clearly shows that human work is irreplaceable by robots in the field of research, analyses and design. This also applies to the creation, use and interpretation of rules and procedures, negotiation, learning, training and leading people. In Deloitte's material entitled Why Not Be Afraid of Robots (2018), clear information has been elaborated. It was also used in the study (Kotíková et al, 2019), as shown in Figure 1.

Only a relatively small part of professions in the Czech economy will not be threatened by digitalization at all in comparison to developed economies. The authors of the Czech study on the effects of digitalization on the labour market built on the study of Frey and Osborn (2013), when they transferred the results concerning the probability of the threat by digitalization from the American Standard Occupational Classification (SOC) to the international CZ-ISCO classification used in the Czech Republic. (Chmelar̆ et al., 2015) 
Table 2. Categorization of work tasks

\begin{tabular}{|l|ll|}
\hline \multicolumn{2}{|c|}{ Routine } & \multicolumn{1}{c|}{ Non-Routine } \\
\hline & Repair and renovation (real estate, machines, & works of art) \\
Machine operator & Services and personal care \\
Packaging and palletizing & Driving vehicles \\
Batching & Research and analyses \\
\hline Counting & Evaluation and planning \\
Accounting & Design creation \\
Data collection and processing & Establishing rules and procedures \\
Proofreading of text and data & Use and interpretation of rules \\
Length/weight/temperature & Negotiation, lobbying \\
measurement & Organizing \\
Quality check & Teaching and training \\
& Leadership \\
& Entertainment and presentation \\
&
\end{tabular}

Source: Kotíková et al. (2019)

The study "Impacts of Digitalization on Employment and Social Security of Employees" (Kohout, Palíšková, 2017) states that it can be concluded from today's trends in labour markets that an individual with more comprehensive knowledge and skills, being able to think and make decisions in a broader context and open to life-long learning tends to be more successful in the labour market. (Kotíková et al, 2019)

In particular, the following knowledge and skills are expected to be required in the future:

- Digital literacy as part of the basic education of every individual. In particular, the ability to use technology to solve problems effectively and the ability to work effectively with information. The ability to continuously learn new trends in technology and constantly develop IT knowledge and skills is related to this.

- Narrow specialization in one field will decline and the so-called T-shaped professional, i.e. person with professional knowledge in a T-shape - at the same time deep and broad knowledge will be required. More precisely: Depth of Expertise, i.e. professional deep knowledge in one field, and at the same time Breadth of Knowledge, i.e. broad knowledge across many fields, accompanied by the ability to communicate and apply critical thinking, etc. This ability to think interdisciplinary is a necessary prerequisite for innovation. It will be necessary to be aware of the whole system due to the interconnection of technologies, production processes and the entire value (also valuecreating) chain.

- In addition to hard skills (i.e. professional, technical, language, etc.), the importance of soft skills will continue to grow. These are mainly communication skills, conceptual thinking, team leadership and co-operation skills. 
Table 3. Time horizon for technological substitutability of key skills

\begin{tabular}{|l|l|l|l|}
\hline Less than 5 years & 6-15 years & $\mathbf{1 6 - 3 0}$ years & Over 30 years \\
\hline $\begin{array}{l}\text { Optimization and } \\
\text { planning }\end{array}$ & Fine motor skills & Mobility & Logic \\
\hline $\begin{array}{l}\text { Recognition of known } \\
\text { categories }\end{array}$ & $\begin{array}{l}\text { Creating new } \\
\text { categories }\end{array}$ & Group interaction & $\begin{array}{l}\text { Problem-solving } \\
\text { ability }\end{array}$ \\
\hline Obtaining information & $\begin{array}{l}\text { Presentation of } \\
\text { results }\end{array}$ & $\begin{array}{l}\text { Natural language } \\
\text { creation }\end{array}$ & Creativity \\
\hline Navigation & Sensorics & & $\begin{array}{l}\text { Natural language } \\
\text { understanding }\end{array}$ \\
\hline Gross motor skills & & $\begin{array}{l}\text { Social and emotional } \\
\text { skills }\end{array}$ \\
\hline
\end{tabular}

Source: Kotíková et al. (2019)

Perceiving a new set of skills required in a changing business environment during and after pandemics brings insecurity and danger of interpersonal conflicts. Fields such as healthcare, services and education have rapidly transformed from conventional to remote forms of work and now require virtual skills. Independent work and effective communication are the most important skills for their workforce during the current and post-pandemic scenario.

However, the phenomenon of homeworking has categorized the labour market into "good jobs" and "bad jobs". For this reason, the employment balance is unfairly skewed in favour of those who have the right kind of skills compared to workers in roles whose nature prohibits homeworking. (Al-Youbi et al, 2020.) (Dingel, Neiman, 2020).

Table 4. Professions with the highest and lowest share of substitutable skills in the 5-year horizon

\begin{tabular}{|l|l|}
\hline $\begin{array}{l}\text { Professions with the highest share of } \\
\text { substitutable skills in the 5-year horizon }\end{array}$ & $\begin{array}{l}\text { Professions with the lowest share of } \\
\text { substitutable skills in the 5-year } \\
\text { horizon }\end{array}$ \\
\hline $\begin{array}{l}\text { Quality controllers and testers, laboratory } \\
\text { technicians (excluding food and beverages) }\end{array}$ & Dentists \\
\hline Word processing workers, scribes & $\begin{array}{l}\text { Biologists, botanists, zoologists and } \\
\text { related professionals }\end{array}$ \\
\hline Sales and transport agents, customs declarants & Veterinary surgeons \\
\hline Accounting clerks & Civil engineers \\
\hline $\begin{array}{l}\text { Professionals of labour offices and } \\
\text { employment agencies }\end{array}$ & $\begin{array}{l}\text { Geologists, geophysicists and related } \\
\text { workers }\end{array}$ \\
\hline Data registration and archive staff & $\begin{array}{l}\text { Specialists in the field of optics and } \\
\text { optometry }\end{array}$ \\
\hline $\begin{array}{l}\text { Medical record and health information } \\
\text { technicians }\end{array}$ & $\begin{array}{l}\text { Members of the Fire and Rescue Service } \\
\text { and firefighters of other fire protection } \\
\text { units }\end{array}$ \\
\hline Cashiers and ticket sellers & $\begin{array}{l}\text { Chemical engineers and specialists in } \\
\text { related fields }\end{array}$ \\
\hline Clerks not elsewhere specified & Civil architects \\
\hline $\begin{array}{l}\text { Information service workers not elsewhere } \\
\text { specified }\end{array}$ & Pilots, navigators and flight technicians \\
\hline Librarians & Physicists and astronomers \\
\hline
\end{tabular}

Source: Kotíková et al. (2019) 


\subsection{Results of digitalization of education}

In the field of education, a form of mass online courses was used during the pandemic, where one lecturer could be watched by thousands of students at a time. The number of students who attend online lectures is practically non-existent. (An example is Anadolu University in Eskisehir, Turkey, where the authors of the article worked at the Faculty of Engineering in 2019). However, these courses lack a personal approach, where the course leaders do not have the capacity to answer directly the specific questions of individual students. The lecturer is thus forced to answer individual questions in writing, which makes his work very difficult. A possible solution is to use artificial intelligence. However, it cannot replace human assistants, let alone a living lecturer. At the same time, it should be emphasized that the comprehension of the written text of both pupils, students and university students differs considerably from the comprehension of oral interpretation, as can be seen from the following chart.

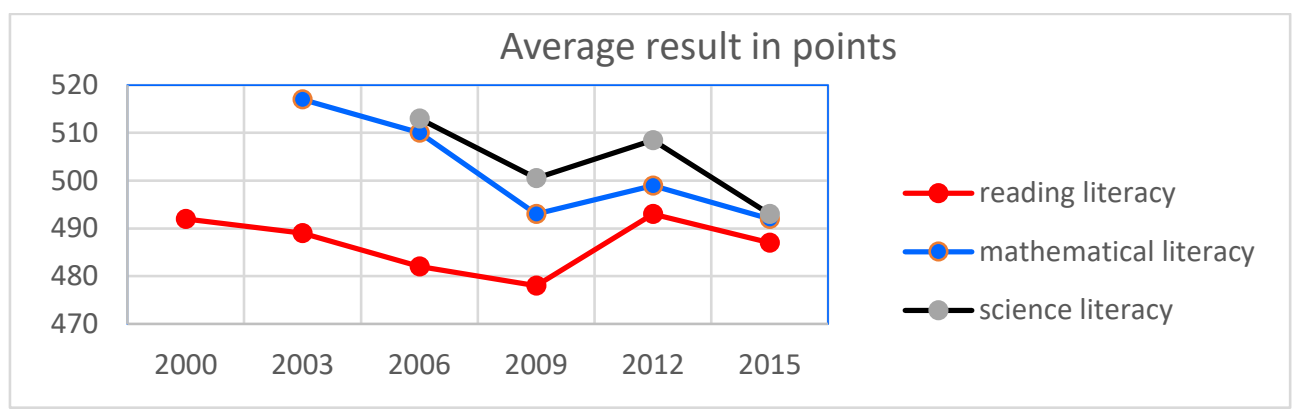

Figure 1. Changes in the results of Czech pupils in the areas of monitored literacy since 2000

Source: authors own processing

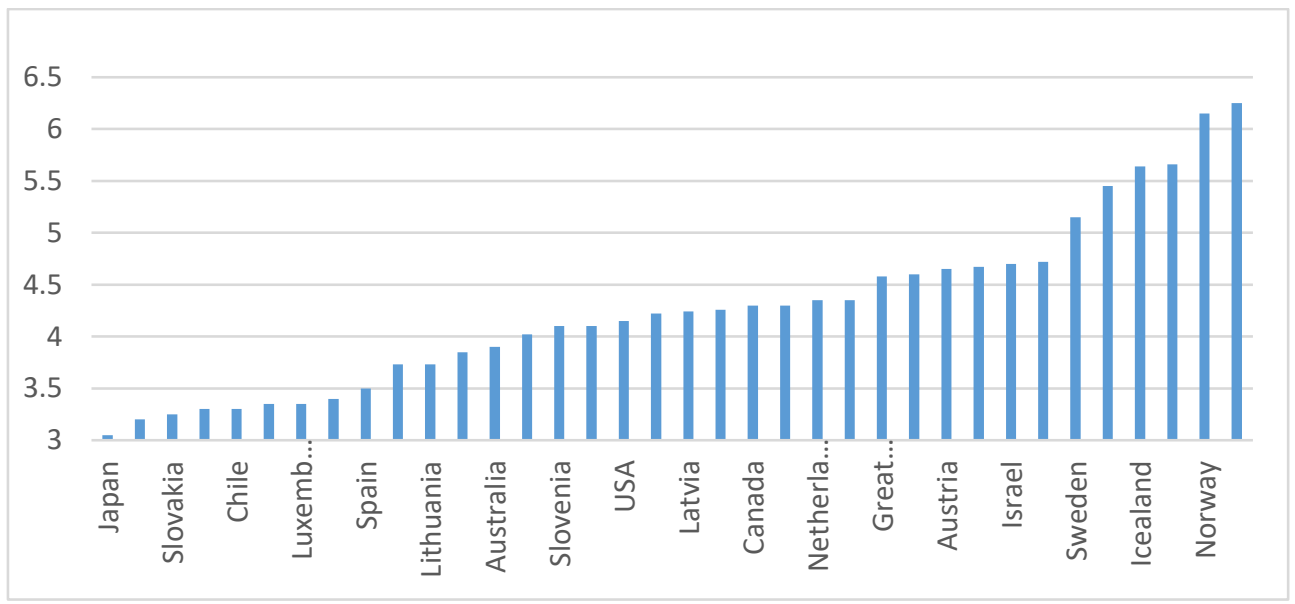

Figure 2. Percentage of GDP spent on education (2015)

Source: authors own processing 
Table 5. Students at universities by groups of fields of education in the Czech Republic

\begin{tabular}{|l|r|r|r|r|}
\hline & $\mathbf{2 0 1 0}$ & $\mathbf{2 0 1 3}$ & $\mathbf{2 0 1 7}$ & $\begin{array}{r}\mathbf{2 0 1 7 / 2 0 1 0} \\
\text { share in } \\
\text { \% }\end{array}$ \\
\hline Universities in total & 395,981 & 367,779 & 298,817 & 75.5 \\
\hline Natural sciences & 32,064 & 31,998 & 27,533 & 85.9 \\
\hline Technical sciences & 86,579 & 82,351 & 65,320 & 75.4 \\
\hline $\begin{array}{l}\text { Agriculture, forestry and veterinary } \\
\text { sciences }\end{array}$ & 14,990 & 14,445 & 13,210 & 88.1 \\
\hline $\begin{array}{l}\text { Healthcare, medical and pharmacological } \\
\text { sciences }\end{array}$ & 28,734 & 30,838 & 31,027 & 108.0 \\
\hline Humanities and social sciences & 67,297 & 63,535 & 50,279 & 74.7 \\
\hline Economic sciences & 99,084 & 85,222 & 60,504 & 61.1 \\
\hline Law an legal sciences & 16,162 & 13,889 & 13,607 & 84.2 \\
\hline Pedagogy, teaching and social care & 48,403 & 41,064 & 31,691 & 665.5 \\
\hline Culture and art sciences & 10,236 & 10,004 & 9,355, & 91.4 \\
\hline
\end{tabular}

Source: authors own processing

Requirements for knowledge and competencies for the future labour market must be based on quality ICT competencies focused theoretically and practically, focusing on a broad base of natural sciences as well as soft competencies. The requirement for learning to learn and to work on personal improvement throughout the whole life is repeatedly emphasized. Education must be shifted from encyclopaedic knowledge to flexible preparation for personal and professional life, understanding of systems and contexts, including life-long continuous education.

In addition to hard skills (i.e. professional, technical, language, etc.), the importance of soft skills (i.e. communication, co-operation, self-management, etc.) is growing. These include mainly critical thinking, the ability to share and co-operate, stress resistance, the ability to react quickly and make decisions, communicate and think conceptually. These soft skills are an essential prerequisite for effective team co-operation, including virtual teams. (Kohout et al, 2017).

It is becoming increasingly clear that after the ongoing Fourth Industrial Revolution (Industry 4.0), the Fifth Industrial Revolution (Industry 5.0) must logically follow. Although Industry 5.0 does not yet have a clear and unambiguous definition, it can be said that it is a vision of the return of man and his creativity to the production process. (Bezdíček, 2021)

\section{Discussion}

The COVID-19 pandemic is very similar to the Spanish, Hong Kong, Asian and swine flu pandemics in terms of spreading around the world. (Akini et al, 2020). The good news is that decades of fighting compared to the HIV epidemic provided important lessons for controlling the COVID-19 pandemic. (El-Sadr, 2020)

In addition, new digital industries based on the use of the Internet, big data and artificial intelligence could launch a completely new wave of growth in the Czech economy. These technologies are already sufficiently developed and their applications are gaining strength across industries and in society.

The Czech Republic has a strong foundation for the quick and efficient implementation of the digitalization process. In some fields, such as financial services and manufacturing, the country has already achieved a higher rate of digitalization than the five largest European economies. In addition, there is a large number of talented graduates in technical fields, 
a quality digital infrastructure and a less conservative approach in terms of the use of new technologies than Western or Northern Europe. In key areas for successful digitalization, such as the introduction of digital skills and tools at the level of individuals and companies or the level of participation in life-long learning systems, the Czech Republic achieves aboveaverage results in Central and Eastern Europe.

\section{Conclusions}

The COVID-19 crisis is unique in modern history and still faces long-term consequences to come. Despite this uncertainty, however, it is important to now launch an academic debate on their potential impacts. This means that COVID-19 will continue to stimulate the processes of cost-saving technology changes. (Brakman et al, 2021)

The introduction of automation, robotics, digitalization and artificial intelligence in different fields of the industry is the largest in mechanical engineering and electrical engineering in the Czech Republic.

Within the National Centre for Industry 4.0 in the Czech Republic, the Construction 4.0 platform was newly established in 2021, with the ambition of connecting major research institutes, especially at technical universities, with progressive construction companies and offering space for mutual co-operation. The aim is, among other things, the introduction of new technologies, including the use of the principles of Industry 4.0 in the construction activity and increasing the competitiveness of the Czech Republic in this area on a European scale. (BIM News, 2021)

COVID-19 is both a global health crisis and a large labour market crisis and an economic crisis that has had and continues to have a huge impact on society. Fortunately, social capital still exists during this crisis, and cultural change has taken place in society. (Gandasari et al, 2020)

It is a pity that the academic sphere at technical universities has so far captured the advent of Industry 4.0 only in some fields in its study programmes. At the same time, Industry 5.0 the approaching and emerging Fifth Industrial Revolution has not practically been taken into account up to now. Subjects focused on interdisciplinarity, creativity, flexibility, emotional intelligence and other soft skills are constantly reduced in many technical programmes and are considered to be marginal, with the fact that they belong to the teaching of humanitiesoriented programmes. Thus, in the practice of industrial and construction companies, this shortcoming in the training of civil engineers is usually solved by management by using the offer of soft skills training by private training companies. At the same time, the academic sphere has the potential to train engineers at technical universities to educate students and future graduates in this type of knowledge and skills. The COVID-19 pandemic has strongly affected the labour market. It has shown that in addition to hard skills, communication skills, conceptual thinking, team leadership ability and co-operation, stress resistance and other soft skills represent essentials for the "covid" generation and generations to come.

\section{References}

1. Akin, L., \& Gözel, M. G. (2020). Understanding dynamics of pandemics. Turkish Journal of Medical Sciences, 50, 515-519.

2. Al-Youbi, A. O., Al-Hayani, A., Rizwan, A., \& Choudhry, H. (2020). Implications of COVID-19 on the Labour Market of Saudi Arabia: The Role of Universities for a Sustainable Workforce. Sustainability, 12(17), Art. No.7090.

3. Bezdíček, J. (2021). Průmysl 5.0 vrací do automatizovaného výrobního procesu lidský prvek a jeho kreativitu. IT systems, IT řešení pro výrobní podniky I. 
4. BIM News. (2021, June 18). Vznikla platforma Stavebnictví 4.0 pro spolupráci mezi firmami a výzkumnými pracovišti. https://bimnews.cz/platforma-stavebnictvi-4-0vznikla-v-narodnim-centru-prumyslu-4-0/

5. Brakman, S., Garretsen, H., \& van Witteloostuijn, A. (2021). Robots do not get the coronavirus: The COVID-19 pandemic and the international division of labour. Journal of International Business Studies, 52, 1215-1224.

6. Český statistický úřad. (2021, August 3). Výběrové šetření pracovních sil. https://www.czso.cz/csu/xc/vyberove_setreni_pracovnich_sil_vsps

7. Český statistický úr̆ad. (2021, February 17). Co je ESS a jak pracuje. https://www.czso.cz/csu/czso/co_je_ess_a_jak_pracuje

8. Český statistický úřad. (2021, February 17). Zákon č.89/1995 Sb., o státní statistické službě. https://www.czso.cz/csu/czso/zakon_o_statni_statisticke_sluzbe

9. Dingel, J. I., \& Neiman, B. (2020). How many Jobs Can be Done at Home? Journal of Public Economics, 189(C).

10. El-Sadr, W. M. (2020). What one pandemic can teach us in facing another. AIDS, 34(12), 1757-1759.

11. Gandasari, D., \& Dwidienawati, D. (2020). Content analysis of social and economic issues in Indonesia during the COVID-19 pandemic. Heliyon, 11(6).

12. Gill, M. J. (2021). High Flying Business Schools: Working Together to Address the Impact of Management Education and Research on Climate Change. University of Oxford. Journal of Management Studies, 58(2).

13. Chmelař, A. et al. (2015). Dopady digitalizace na trh práce $v \check{C} R$ a EU. Oddělení strategie a trendů Evropské unie (OSTEU). https://www.vlada.cz/assets/evropskezalezitosti/analyzy-EU/Dopady-digitalizace-na-trh-prace-CR-a-EU.pdf

14. Kohout, P., \& Palíšková, M. (2017). Dopady digitalizace na zaměstnanost a sociální zabezpečení zaměstnanců - analytická studie 2017. SICAV a VŠE

15. Kotíková, J., Kraus, A., Modrá, J., Št’astnová, P., Váňová, J., \& Víšek, P. (2019). Dopady digitalizace, automatizace a robotizace na trh práce, do oblasti vzdělávání a oblasti sociálnich systémů. VÚPS. http://praha.vupsv.cz/fulltext/vv_008.pdf

16. Lizana, P. A., Vega-Fernadez, G., Gomez-Bruton, A., Leyton, B., \& Lera, L. (2021). Impact of the COVID-19 Pandemic on Teacher Quality of Life: A Longitudinal Study from before and during the Health Crisis. International Journal of Environmental Research and Public Health, 18(7), Art. No. 3764.

17. Mackowiak, P. A. (2021). Prior pandemics. looking to the past for insight into the COVID-19 pandemic. Journal of Community Hospital Internal Medicine Perspectives, 11(2), 163-170.

18. Mujica, G., Sternberg, Z., Solis, J., Wand, T., Carrasco, P., Henao-Martínez, A. F., \& Franco-Paredes, C. (2020). Defusing COVID-19: Lessons Learned from a Century of Pandemics. Tropical Medicine and Infectious Disease, 5(4), Art. No. 182.

19. Nguyen, P.-H., Tsai, J.-F., Nguyen, H.-P., Nguyen, V.-T., \& Dao, T.-K. (2020). Assessing the Unemployment Problem Using a Grey MCDM Model under COVID-19 Impacts: A Case Analysis from Vietnam. The Journal of Asian Finance, Economics and Business, 7(12), 53-62.

20. Randl, D. (2021, August 5). Digitalizace jako dalši motor růstu české ekonomiky? McKinsey Prague. https://prg.ai/digitalizace-ai-umela-inteligence-cesko-ekonomika/

21. Travis, D. (2021, August 5). Desk research. The what, why and how. User focus. https://www.userfocus.co.uk/articles/desk-research-the-what-why-and-how.html 